\title{
Keselamatan Wisatawan Dalam Atraksi Cliff Jumping Yang Terdapat Di Pantai Tegal Wangi Jimbaran Sebagai Daya Tarik Wisata Alternatif
}

I Putu Yudi Kurniawan a, 1, I Made Bayu Ariwangsa a, 2

${ }^{1}$ yudik.kurniawan80@gmail.com, 2 bayu_ariwangsa@unud.ac.id

a Program Studi S1 Destinasi Pariwisata, Fakultas Pariwisata,Universitas Udayana, Jl. Dr. R. Goris, Denpasar, Bali 80232 Indonesia

\begin{abstract}
The research is concerning safety standardization of Cliff Jumping attraction in Tegal Wangi Beach is motivated by the local and foreign tourist that not knowing yet about potential and safety standardization of Cliff Jumping attraction on Tegal Wangi Beach. Along with the number of tourist visiting which continue to increase resulting local and foreign tourist need to learning about potential and safety standardization of Cliff Jumping attraction on Tegal Wangi Beach.

The aim of this research is to knowing about potential and standardization of Cliff Jumping attraction to increase tourist attraction of Tegal Wangi Beach. Data sampling was performed by observation, depth interview, documentation and literature study. The data was obtained with descriptive qualitative analysis.

The result of the search shows that safety standardization of Cliff Jumping attraction can be seen in standardization and particular knowing of safety first. Community effort in increasing of Cliff jumping attraction including the effort already being done and the effort that will be done as well as the obstacles faced by the community of Jimbaran Village in increasing of potential Cliff Jumping attraction on Tegal Wangi Beach.
\end{abstract}

Keyword : Safety standardization, Tourist attraction, Alternative tourism

\section{PENDAHULUAN}

Pariwisata saat ini sudah menjadi salah satu gaya hidup yang dilakukan oleh sebagian orang untuk mendapatkan sebuah kepuasan atau sekedar menghilangkan rasa penat dengan pergi ke suatu daerah yang dianggap mampu memberikan pengalaman dan kepuasan tersendiri (kohdyat:2009)

Bali merupakan salah satu tujuan utama para wisatawan karena memiliki potensi dan atraksi wisata yang unik serta terkenal dengan pantainya, khususnya Bali selatan seperti kuta, seminyak, nusa dua, dan jimbaran. Jimbaran itu sendiri mempunyai sebuah Pantai yang eksotis yaitu Pantai Tegal Wangi dengan pemandangan laut luas yang dapat disaksikan dari atas tebing karang yang curam dan ombak yang besar. Pantai dengan pasir putih ini berada di areal Pura Segara Tegal Wangi, Desa Adat Jimbaran, Kecamatan Kuta Selatan, Kabupaten Badung, Bali.

Salah satu atraksi wisata yang terdapat di Pantai Tegal Wangi Jimbaran adalah Cliff Jumping yang sangat memacu adrenalin dalam perjalanan orang-orang yang ingin mencari tahu daerah peisir sebagai cerita petualangan, Cliff Jumping itu sendiri adalah sebuah tempat atau spot lompatan dari atas tebing yang mengarah ke laut dan memiliki ketinggian tertentu

Tebing lompatan ini berlokasi di pinggiran karang Pantai Tegal Wangi namun hanya memiliki satu Spot (satu tempat lompatan) yang berada di utara Pantai Tegal Wangi, untuk menemukan Cliff Jumping (tebing lompatan) ini harus berjalan sekitar 70 meter karena spot Cliff Jumping (tebing lompatan) ini berada di tengah tengah (Pelosok) Pantai Tegal Wangi yang menghadap ke barat, Cliff Jumping ini memiliki ketinggian hanya sekitar 7 meter tapi selalu ada banyak wisatawan yang melompat di Spot tersebut untuk memamerkan keterampilan mereka.

Namun dalam melakukan kegiatan extrim Cliff Jumping di Pantai Tegal Wangi tersebut tidak diawasi oleh orang yang ahli dalam melakukan atraksi Cliff Jumping ataupun balawista (badan penyelamat wisata tirta) yang biasa disebut penjaga pantai yang akan memberikan pertolongan kepada wisatawan yang mendapat musibah seperti tenggelam atau terseret arus yang nantinya akan mengurangi angka kecelakaan di pantai, oleh karena itu dibutuhkan standardisasi yang ideal sebagai acuan dalam melakukan atraksi Cliff Jumping ini. Berdasarkan penggambaran di atas maka akan di bahas pada bab selanjutnya mengenai keselamatan wisatawan dalam atraksi Cliff Jumping yang terdapat di Pantai Tegal Wangi sebagai daya tarik wisata alternatif.

\section{KEPUSTAKAAN}

Pada penelitian ini mengacu pada penelitian sebelumnya yang pertama, Penelitian yang dilakukan oleh Robertus San (2016) dengan Judul "Partisipasi Masyarakat Dalam 
Pengembangan Daya Tarik Wisata Pantai Pandawa, kabupaten Badung - Desa Kutuh" dan penelitian yang kedua yaitu penelitian oleh Agastya (2014) dengan judul "Penerapan K3 di Benoa Tirta Harum Dive and Watersport.

(Sumakmur:1993) berpendapat bahwa, pada tinjauan lebih dekat Keamanan kesehatan keselamatan kerja dalam istilah sehari-hari sering disebut dengan safety saja, secara filosofi diartikan sebagai suatu pemikiran dan upaya untuk menjamin keutuhan dan kesempurnaan baik jasmaniah maupun rohaniah manusia pada umumnya serta hasil budaya dan karyanya. Dari segi keilmuan diartikan sebagai suatu pengetahuan dan penerapannya dalam usaha mencegah kemungkinan terjadinya kecelakaan.

Keamanan kesehatan keselamatan kerja diartikan sebagai kondisi yang bebas dari resiko kecelakaan atau kerusakan dengan dengan resiko yang sangat kecil dibawah nilai tertentu. kesehatan, keselamatan kerja adalah suatu kondisi yang terbebas dari ancaman bahaya yang mengganggu proses aktivitas dan mengakibatkan terjadinya cidera, penyakit, serta kerugian dengan mengenali hal-hal yang dapat menimbulkan ancaman atau bahaya yang salah satunya sangat diperlukan dibidang pariwisata. Dalam penelitian ini standarisasi (K3) sangat diperlukan sebagai acuan dalam atraksi Cliff Jumping yang terdapat di Pantai Tegal Wangi Jimbaran

\section{METODE PENELITIAN}

Penelitian ini dilakukan di kawasan Pantai Tegal Wangi Jimbaran, Kabupaten Badung, Provinsi Bali. ruang lingkup dalam penelitian ini yaitu Keselamatan wisatawan dalam atraksi Cliff Jumping di Pantai Tegal Wangi berdasarkan cara aman dalam melakukan atraksi Cliff Jumping. Dalam penelitian ini ada dua Jenis data yang digunakan yaitu data kualitatif dan kuantitatif dengan sumber data primer (Umar:2003), data sekunder (Sugiono:2013), dan dokumentasi di internet (google map) tentang lokasi dari Pantai Tegal Wangi.

Ruang Lingkup Permasalahan dalam penelitian ini yaitu Keamanan, Kesehatan, dan Keselamatan wisatawan

Teknik pengumpulan data dalam penelitian ini dengan "metode observasi melalui hasil wawancara dan juga studi dokumenter (Sugiyono:2013) dan studi kepustakaan seperti literatur, beberapa buku dan dokumen, serta dari penelitian terdahulu" . (Nazir:1998).

"Data yang didapat akan dianalisis secara deskriptif yang sebelumnya diperoleh melalui mengumpulkan catatan deskripsi dari lapangan, yaitu semua informasi baik hasil observasi, wawancara mendalam, dokumentasi, studi kepustakaan serta data dari beberapa media seperti internet kemudian akan diinterprestasikan berdasarkan konsep-konsep sesuai pemahaman peneliti menjadi catatan yang berbentuk uraian yang menggambarkan sesuai kondisi yang terkait penelitian yang sifatnya menerangkan suatu daya tarik wisata" . (M.KhaerulAkham:2012).

\section{HASIL DAN PEMBAHASAN}

\subsection{Keselamatan wisatawan dalam atraksi} Cliff Jumping di Pantai Tegal Wangi

Standardisasi adalah penetapan standar untuk memberi batasan yang spesifik dalam penggunaan beberapa kegiatan atau objek dimana standardisasi merupakan hal yang sangat mendasar dalam studi tentang Alternative Tourism (lady Mainlanni:2009 terlebih lagi banyak wisatawan yang tidak mengetahui resiko dan mengabaikan keselamatan mereka

Resiko yang dapat terjadi di Cliff Jumping tersebut adalah tenggelam karena terhempas ombak, berbentur dengan karang, dan cara jatuh yang salah akan mengakibatkan cidera oleh karena itu standardisasi sangat perlu diterapkan

Hal ini diungkapkan oleh salah satu informan sean mc aloney selaku wisataan asal Australia adalah sebagai berikut:

"Beberapa wisatawan yang berwisata ke Pantai Tegal Wangi dan mencoba atraksi Cliff Jumping tidak begitu mengetahui resiko apa saja yang dapat terjadi karena lebih mementingkan rasa kepuasan dan menghilangkan rasa penasaran mereka padahal hal yang tidak diinginkan bisa saja terjadi"

(Wawancara Tanggal 13 juni 2018)

Dari definisi standardisasi di atas standardisasi dalam melakukan sebuah lompatan Cliff Jumping yang terdapat di Pantai Tegal Wangi dilakukan hanya dengan Play at your own risk karena dalam melakukan lompatan pada Spot Cliff Jumping ini memang 
tidak ada perlengkapan khusus sebagai penunjang. Sebagai gantinya yang di butuhkan adalah pengetahuan khusus dalam melakukan lompatan pada Spot Cliff Jumping.

Hal ini di ungkapkan oleh salah satu informan I Kadek Budi Utama selaku penduduk lokal sekitar Pantai Tegal Wangi adalah sebagai berikut: "Dulunya saya meragukan untuk mengajak teman teman saya atau masyarakat lokal lainnya untuk mendukung potensi atraksi Cliff Jumping yang terdapat di Pantai Tegal Wangi karena saat itu saya belum tahu betul mengenai standardisasi yang ideal dalam melakukan atraksi Cliff Jumping tersebut, karena hal ini termasuk hal baru bagi masyarakat di sini termasuk saya, namun karena rasa keingintahuan itu maka saya mencoba sekali melakukan lompatan pada Spot Cliff Jumping tersebut yang pastinya sudah melakukan survei dan persiapan terlebih dahulu, setelah berhasil melakukan lompatan di Spot Cliff Jumping tersebut sekarang saya sudah yakin bahwa atraksi Cliff Jumping tersebut aman dilakukan oleh semua orang asalkan memiliki pengetahuan khusus sebagai acuan dan melakukan persiapan yang matang dalam melakukan atraksi Cliff Jumping Tersebut". (Wawancara,Tanggal 27 Mei 2016).

Berikut adalah beberapa hal yang harus diperhatikan saat melompat di Cliff Jumping Pantai Tegal Wangi

1. Mencari Lokasi yang Bebas dari Batu dan Karang

Sebelum melakukan sebuah lompatan pada Spot Cliff Jumping disarankan agar mencari Spot atau lokasi jatuh yang bebas dari batu atau karang karena lokasi jatuh yang salah akan mengakibatkan cidera.

2. Mengetahui Kedalaman Air

Sebelum melakukan Atraksi Cliff Jumping disarankan agar mengetahui kedalaman air agar tidak menghantam dasar air, hanya dikarenakan tempat melompat yang kurang dalam, juga harus mengetahui lokasi mana yang paling tepat untuk terjun. Kedalaman air harus sesuai dan aman dengan tingginya tebing dari tempat kita melompat, perhatikan pula semakin tinggi tebing, semakin keras pula akan menghantam air.

3. Perhatikan Arah dan Kondisi Angin

Angin yang terlalu kencang dapat mengubah titik jatuh kita menjadi lebih jauh atau melenceng. Untuk itu harus berhati-hati jika pada saat angin kencang saat kita hendak melakukan sebuah lompatan.

4. Memilih Lokasi yang Tidak Berombak

Untuk seseorang yang melakukan atraksi Cliff Jumping, sebaiknya tidak memilih lokasi yang berombak besar. Hal ini untuk mengurangi resiko terbawa ombak ke tengah laut. Serta ombak yang menabrak karang juga dapat mengakibatkan luka gores atau cidera.

5. Mengetahui Posisi Aman dan Benar

Sebelum melakukan atraksi Cliff Jumping sebaiknya berlari dan melompat sejauh mungkin, agar resiko tergores bibir tebing dapat diminimalisir karena posisi terjun yang kurang tepat.

6. Memiliki Kemampuan Berenang dan Ada yang Mengawasi

Saat melakukan atraksi Cliff Jumping dibutuhkan kemampuan untuk menahan nafas dan kembali ke permukaan, dan disarankan hanya bagi orang yang memiliki kemampuan berenang, karena saat melakukan Cliff Jumping otomatis kedalaman air akan lebih tinggi dari tinggi badan kita, agar tidak terbentur dengan dasar air.

Dalam melakukan atraksi Cliff Jumping disarankan agar dalam pengawasan teman atau saudara dimana ketika kita membutuhkan pertolongan atau saat terjadi sesuatu yang tidak diinginkan seperti tergores bibir karang atau terseret ombak. Standardisasi memiliki peran yang penting dalam keamanan dan kenyamanan dari kegiatan wisatawan, standardisasi ini dirancang agar penduduk lokal dan wisatawan asing maupun lokal merasa aman dalam melakukan kegiatan ekstrim dari atraksi Cliff Jumping ini. Standardisasi di atas merupakan standaridsasi yang ideal untuk digunakan sebagai acuan dalam melakukan atraksi Cliff Jumping dan hingga saat ini standardisasi di atas tetap digunakan sebagai standardisasi keamanan dan berjalan dengan lancar.

\section{a. SIMPULAN DAN SARAN}

A. SIMPULAN

Sejak ditemukannya Pantai Tegal wangi pada tahun 2006, mulai banyak wisatawan yang berdatangan dengan berbagai macam motivasi seperti berenang, memancing maupun melakukan sesi foto pre wedding dengan latar pemandangan laut yang indah 
Selain itu terdapat keunikan dari pantai ini yaitu sebuah spot Cliff Jumping yang terdapat pada bagian selatan pantai yang sudah mulai banyak diketahui wisatawan

Cliff Jumping ini memiliki keunikan tersendiri yang merupakan satu-satunya di Bali Selatan, Cliff Jumping tersebut terbilang masih baru, wisatawan yang datang untuk mencoba atraksi tersebut lebih banyak didominasi oleh wisatawan lokal karena memang Cliff jumping ini berada di pantai yang Hidden (tersembunyi) dan belum banyak wisatawan yang mengetahui, semakin tersebarnya informasi tentang keberadaan Cliff Jumping ini, kini wisatawan yg dating semakin bertambah jumlahnya.

Wisatawan yang mengunjungi Spot atraksi Cliff Jumping ini bertujuan untuk menghilangkan rasa penasaran, refreshing atau sekedar menghilangkan rasa penasaran, refreshing atau sekedar menghilangkan stress yang dialami dengan memacu adrenalin dan menaklukan rasa takut mereka.

\section{B. SARAN}

Berdasarkan hasil pembahasan yang telah dipaparkan di atas maka saran kepada pihak penduduk lokal dan pemerintah yang dapat diberikan sebagai berikut.

Saran kepada penduduk lokal :

1. Terkait promosi yang kurang, diharapkan penduduk lokal dan pemerintah agar lebih mempromosikan keberadaan Pantai Tegal Wangi, agar jumlah wisatawan yang datang semakin meningkat jumlahnya

2. Diharapkan penduduk lokal dan pemerintah mensosialisasikan keberadaan Cliff Jumping yang ada di Pantai Tegal Wangi sebagai daya tarik wisata alternatif, sehingga keberadaan Spot Cliff Jumping Pantai Tegal Wangi semakin meluas

3. Diharapkan penduduk lokal merancang papan tulisan bertuliskan kewaspadaan dalam melakukan atraksi Cliff Jumping, serta memperbaiki jalan akses tangga menuruni batu kapur, sehingga memudahkan wisatawan untuk mengunjungi Pantai Tegal Wangi.

Saran kepada wisatawan:

Diharapkan kepada wisatawan yang berwisata di Pantai Tegal Wangi agar mengikuti ketentuan yang berlaku yaitu setidaknya memiliki pengetahuan khusus jika hendak melakukan atraksi di Spot Cliff Jumping karena kegiatan ini dapat dikatakan berbahaya, pengunjung yang hendak melakukan atraksi Cliff jumping disarankan agar diawasi oleh teman atau saudara.

\section{DAFTAR PUSTAKA}

M.kasrul (2009) hal 6. 3. Klasifikasi Perjalanan Wisata. Undang-Undang RI No 10 Tahun 2009 Tentang kepariwisataan.

Kohdyat 2009. Pengantar Ilmu Pariwisata. Yogyakarta

Lady mainlanni. 2009 penggunaan standardisasi dan penentuan ukuran

Nazir Muhammad. 1998. Metode Penelitian, Jakarta: Galia Indonesia.

Sugiyono. 2013. Metode Penelitian Pendidikan (Pendekatan kuantitatif, Kualitatif, dana R\&D). bandung : Alfabeta

Sumakmur. (2009) P.K. Higiene Perusahaan dan Kesehatan Kerja. Jakarta.

Umar Metodelogi Penelitian Untuk Skripsi dan Tesis Bisnis,Jakarta. : PT. Gramedia Pustaka 